\title{
Hypertrophic Effect of Unavailable Carbohydrate on Cecum and Colon in Rats
}

\author{
Fumiko KONISHI, Tsuneyuki OKU, and Norimasa HOSOYA ${ }^{1}$ \\ Department of Nutrition, School of Health Sciences, Faculty of Medicine, \\ University of Tokyo, Hongo, Bunkyo-ku, Tokyo 113, Japan
}

(Received September 20, 1983)

\begin{abstract}
Summary The effects of unavailable carbohydrate on the cecum and colon were investigated in rats raised on diets containing $20 \%$ of glucomannan or cellulose for 8 weeks. Glucomannan ingestion caused the increase of cecum and colon weights, and the effect was greater in the cecum than in the colon. However, on ingestion of cellulose, a remarkable increase in tissue weight was observed in the colon rather than in the cecum. Measurement of DNA, RNA and protein in cecal and colonic mucosa demonstrated that the cecal enlargement caused by glucomannan was dependent on the increases in both number and size of mucosal cells, and that the cecal and colonic enlargements caused by cellulose and the colonic enlargement caused by glucomannan resulted from an increase in the number of mucosal cells; i.e., hyperplasia. $(\mathrm{Na}+\mathrm{K}) \mathrm{ATPase}$ activity of the cecal and colonic mucosa in the cellulose and glucomannan groups was significantly higher than that in the control group. Thus, $(\mathrm{Na}+\mathrm{K})$ ATPase activity was increased proportionally to the intensity of the process of tissue enlargement.
\end{abstract}

Key Words cecum, colon, hyperplasia, hypertrophy, unavailable carbohydrate

The ingestion of unavailable carbohydrate increases fecal volume and shortens gastrointestinal transit time (1-3) and such unavailable carbohydrate plays a protecting role against diverticular disease, constipation, hemorroids and colonic cancer (4-7). It has also been found that dietary unavailable carbohydrate increases the wet weight of large bowel in the rat (8).

Previous reports have demonstrated that the long-term ingestion of unavailable carbohydrate increases the wet weight of cecum and colon in rats (9-11). The effects are different in particular between water-soluble and water-insoluble unavailable carbohydrates. The effect of water-soluble material such as glucomannan was greater on the cecum than on the colon, and that of water-insoluble material such as

\footnotetext{
1 小西史子, 奥 恒行, 細谷憲政
} 
cellulose is stronger on the colon than on the cecum. However, it is still not clear whether the enlargement of cecum and colon caused by unavailable carbohydrate is induced by the increase of mucosal cell numbers or the increase of cellular size.

The purpose of the study reported herein is to examine the mode of cecum and colon enlargement by the ingestion of unavailable carbohydrate and to demonstrate the biochemical changes in the tissues.

\section{METHODS}

1. Animals. Male Wistar weanling rats, initially weighing $40-50 \mathrm{~g}$, were fed on diets containing $20 \%$ of glucomannan or cellulose ad libitum for 8 weeks. Six rats were randomly assigned to one of three dietary groups: control group, glucomannan group and cellulose group. Each group was housed in a cage at $25 \pm 3^{\circ} \mathrm{C}$. The animals were fasted for $16 \mathrm{~h}$ with free access to water before decapitation.

2. Diet composition. Basal diet (control) contained corn starch $67 \%$, casein $21 \%$, corn oil $7 \%$, salt mixture $4 \%$ and vitamin mixture $1 \%(10)$. Salt mixture and vitamin mixture were purchased from Nihon Clea Co. (Tokyo). The two unavailable carbohydrates were substituted at the $20 \%$ level for an equal weight of corn starch: glucomannan (Amorphophallus Konjac C Koch, Simizu Chemical Co., Mihara, Hiroshima) and cellulose with about 620 glycoside bonds (KC flok W-50, Sanyokokusaku Pulp Co., Tokyo).

3. Preparation of cecal and colonic mucosa homogenates. After decapitating a rat, the cecum was cut at the ileocecal and cecocolonic junctions and anus. The cecum and colon were longitudinally opened, rinsed with ice-cold saline, and carefully blotted using paper towel. After measurement of the wet weight of whole tissue, the mucosa was peeled off using microscopic slide glass on the ice-cold glass plate. The isolated mucosa was homogenized in 19 volumes of STE buffer ( $250 \mathrm{mM}$ sucrose, $10 \mathrm{mM}$ Tris- $\mathrm{HCl}, 5 \mathrm{mM}$ EDTA) ( $\mathrm{pH}$ 7.45). The homogenates were used for the determinations of DNA, RNA, protein and $(\mathrm{Na}+\mathrm{K})$ ATPase activity after adequate dilution.

4. Measurement of $D N A, R N A$, protein and $(N a+K) A T P a s e$ activity. The extraction of nucleic acids from the homogenates was carried out according to the Schmidt-Thannhauser-Schneider method(12). DNA was measured by the Burton method using diphenylamine (13). Calf thymus DNA was used as a standard. RNA was measured by the Munro and Fleck method using orcinol (14). RNA from yeast was employed as a standard. The protein was determined by the method of Lowry et al. (15) using bovine serum albumin as a standard. ( $\mathrm{Na}+\mathrm{K}$ )ATPase activity was assayed by the modified method of Schiffl et al.(16). The inorganic phosphorus content was measured by the method of Fiske and Subbarow (17).

Results were expressed as the mean \pm the standard error of the mean and the differences were evaluated by Student's $t$-test. 


\section{RESULTS}

\section{1) Animal growth and food intake}

When rats were fed on diets containing $20 \%$ of glucomannan or cellulose for 8 weeks, the body weight gain was lower in the group receiving glucomannan than in the control group $(p<0.05)$ (Table 1). The average body weight for the cellulose

Table 1. Increment of cecum and colon weight caused by unavailable carbohydrate ingestion.

Six rats were raised on a diet containing $20 \%$ of unavailable carbohydrate for 8 weeks. Immediately after decapitation, the cecum and colon of rats were cleaned and the wet weight of whole tissue was measured.

\begin{tabular}{lccc}
\hline & Control & Glucomannan & Cellulose \\
\hline Body weight $(\mathrm{g})$ & $271 \pm 7$ & $243 \pm 9^{\mathrm{a}}$ & $283 \pm 10$ \\
Cecum & & & \\
$\quad$ wet weight & $0.478 \pm 0.011$ & $1.428 \pm 0.098^{\mathrm{c}, \mathrm{f}}$ & $0.610 \pm 0.040^{\mathrm{a}}$ \\
$\quad \%$ of body weight & $0.177 \pm 0.023$ & $0.587 \pm 0.024^{\mathrm{c}, \mathrm{f}}$ & $0.216 \pm 0.012$ \\
Colon & & & \\
$\quad$ wet weight & $0.673 \pm 0.011$ & $0.835 \pm 0.043^{\mathrm{b}, \mathrm{f}}$ & $1.133 \pm 0.030^{\mathrm{c}}$ \\
\% of body weight & $0.268 \pm 0.023$ & $0.345 \pm 0.019^{\mathrm{a}}$ & $0.404 \pm 0.019^{\mathrm{b}}$ \\
\hline
\end{tabular}

Each value represents the mean \pm standard error. ${ }^{a, b, c}$ Significantly different from the control group at $p<0.05, p<0.01$ and $p<0.001$, respectively. ${ }^{\mathrm{f}}$ Significantly different from the cellulose group at $p<0.001$.

Table 2. Total DNA, RNA/DNA and protein/DNA in cecal and colonic mucosa of rats fed unavailable carbohydrates.

Animals are the same as described in Table 1. Total mucosa were collected from whole cecum and colon, respectively. After homogenizing the mucosa, DNA, RNA and protein were determined as described in METHODS.

\begin{tabular}{lllll}
\hline & & Control & Glucomannan & Cellulose \\
\hline \multirow{3}{*}{ Cecum } & Total DNA (mg) & $1.32 \pm 0.04$ & $3.47 \pm 0.18^{\mathrm{c}, \mathrm{f}}$ & $1.95 \pm 0.10^{\mathrm{c}}$ \\
& RNA/DNA & $1.20 \pm 0.05$ & $1.56 \pm 0.11^{\mathrm{a}}$ & $1.30 \pm 0.06$ \\
& Protein/DNA & $14.2 \pm 0.4$ & $17.4 \pm 0.5^{\mathrm{c}, \mathrm{d}}$ & $15.3 \pm 0.6$ \\
\hline \multirow{3}{*}{ Colon } & Total DNA (mg) & $1.07 \pm 0.18$ & $1.70 \pm 0.11^{\mathrm{a}}$ & $2.00 \pm 0.16^{\mathrm{b}}$ \\
& RNA/DNA & $1.70 \pm 0.11$ & $1.87 \pm 0.15$ & $2.12 \pm 0.19$ \\
& Protein/DNA & $18.7 \pm 1.2$ & $18.2 \pm 1.0$ & $19.7 \pm 1.4$ \\
\hline
\end{tabular}

${ }^{a, b, c}$ Significantly different from the control group at $p<0.05, p<0.01$ and $p<0.001$, respectively. ${ }^{\mathrm{d}, \mathrm{f}}$ Significantly different from the cellulose group at $p<0.05$ and $p<0.01$, respectively. 
group was not-significantly different from that for the control group. The food intake of the cellulose group was increased significantly compared with that of the control group $(p<0.05)$, while the food intake of the glucomannan group was not significantly different from that of the control group.

\section{2) Weight of cecum and colon}

The wet weight of cecum and colon respectively of rats raised on a diet containing $20 \%$ of glucomannan for 8 weeks was significantly increased compared with that for the control group $(p<0.01)$ (Table 1). The effect of glucomannan on tissue enlargement was greater for the cecum than for the colon. In the rats fed on cellulose diet, the wet weights of cecum and colon increased by about 1.3-fold and 2fold compared to those of the control group, ( $p<0.05$ and $p<0.001$, respectively). Thus, the effect of cellulose ingestion on tissue enlargement was greater for the colon than for the cecum.

\section{3) Composition of cecal and colonic mucosa}

Total DNA content in the cecal and colonic mucosa was significantly higher in the glucomannan and the cellulose groups than in the control group (Table 2). RNA/DNA and protein/DNA ratios did not change in the hypertrophic colon induced by glucomannan or cellulose ingestion and in the hypertrophic cecum induced by cellulose ingestion. However, these ratios in the cecal mucosa enlarged by glucomannan ingestion were significantly increased compared with those of the control group $(p<0.05)$ (Table 2$)$.

These results indicate that the enlargement of cecum and colon induced by cellulose ingestion results from the increase in cell numbers, i.e. hyperplasia. The cecal enlargement caused by glucomannan ingestion results from the increase in both number and size of mucosal cells, i.e. hypertrophic hyperplasia.

4) $(\mathrm{Na}+\mathrm{K})$ ATPase activity in cecal and colonic mucosa

The level of $(\mathrm{Na}+\mathrm{K})$ ATPase activity was stimulated in the cecum and colon

Table 3. $(\mathrm{Na}+\mathrm{K})$ ATPase activity in cecal and colonic mucosa of rats fed unavailable carbohydrates.

Animals are the same as described in Table 1. The homogenates of total mucosa were used for the assay of $(\mathrm{Na}+\mathrm{K}) \mathrm{ATPase}$ activity as described in METHODS.

\begin{tabular}{llc}
\hline & $\begin{array}{c}\text { Cecum } \\
(\mu \text { mol phosphorus produced } / \mathrm{h} / \mathrm{mg} \text { protein })\end{array}$ \\
\hline Control & $3.00 \pm 0.27$ & $2.52 \pm 0.09$ \\
Glucomannan & $5.38 \pm 0.17^{\mathrm{c}, \mathrm{d}}$ & $3.85 \pm 0.19^{\mathrm{c}, \mathrm{e}}$ \\
Cellulose & $4.40 \pm 0.36^{\mathrm{a}}$ & $5.51 \pm 0.37^{\mathrm{c}}$ \\
\hline
\end{tabular}

a,c Significantly different from the control group at $p<0.05$ and $p<0.001$, respectively.

${ }^{\mathrm{d}, \mathrm{e}}$ Significantly different from the cellulose group at $p<0.05$ and $p<0.01$, respectively. 
enlarged by glucomannan or cellulose ingestion (Table 3). $(\mathrm{Na}+\mathrm{K}) \mathrm{ATPase}$ activity in the cecal mucosa was higher in the glucomannan group than in the cellulose group $(p<0.01)$. $(\mathrm{Na}+\mathrm{K}) \mathrm{ATPa} e$ activity in the colonic mucosa was higher in the cellulose group than in the glucomannan group. Thus, the level of $(\mathrm{Na}+\mathrm{K}) \mathrm{ATPase}$ activity was proportional to the extent of the tissue enlargement caused by unavailable carbohydrate ingestion. These results show that the cecal and colonic enlargement caused by unavailable carbohydrate feeding possibly results in changes in physiological function.

\section{DISCUSSION}

In previous papers $(9,10)$, it has been demonstrated that the enlargement of cecum and colon is affected by various factors such as the type, molecular size and amount of unavailable carbohydrate. However, no remarkable differences were observed in the feeding periods between 7 and 13 weeks. The study also suggested that the effects of unavailable carbohydrate ingestion were remarkably different between water-soluble and water-insoluble unavailable carbohydrates. Therefore, glucomannan and cellulose were respectively used as water-soluble and waterinsoluble unavailable carbohydrates in the present study.

When rats were raised on a diet containing cellulose or glucomannan for 8 weeks, the cellulose affected the enlargement of colon more greatly than that of the cecum, while glucomannan had a greater effect on the enlargement of cecum than that of colon. These results appear to show that the extent of tissue enlargement is concerned with the properties and volume of cecal or colonic contents. Food intake in the cellulose group increased significantly compared with that of the control, and the stool weight increased greatly. In the glucomannan group, the food intake was similar to that of the control, but the wet weight of stool was heavier than that of the control. The water content of the stool was greater in the glucomannan group than in the cellulose group. The different effects on the cecum and colon may be related to the water-holding capacity of unavailable carbohydrate. The mechanism of cecal and colonic enlargement caused by unavailable carbohydrate ingestion is still not clear.

Cecal enlargement has been observed in rats fed polyethylene glycol(18) or kaolin (19) and in germ-free rats (20). In all these rats, the volume of cecal content and feces greatly increased. In this study, the intestinal contents and fecal volume also increased remarkably in rats fed on unavailable carbohydrate diet. Therefore, the cecal enlargement caused by unavailable carbohydrate ingestion may be caused by a certain machanism as well as that pertaining to the respective ingestion of polyethylene glycol and kaolin and that operating in germ-free rats. However, the mechanism in question is still unknown.

The elevation of $(\mathrm{Na}+\mathrm{K})$ ATPase activity is observed in the cecum of germ-free rats (20) and rats on polyethylene glycol supplemented diet(18). In the present study, $(\mathrm{Na}+\mathrm{K})$ ATPase activity was markedly elevated in the cecum and colon 
enlarged by unavailable carbohydrate ingestion. The unabsorbable intraluminal materials such as polyethylene glycol and mucopolysaccharides retain much water and trap the cations in the cecum and colon (16). Also, unavailable carbohydrate has an extraordinarily high capacity for the retention of water, sodium, potassium, etc. (21). We speculate that the stimulation of $(\mathrm{Na}+\mathrm{K})$ ATPase activity in hypertrophic tissues might result from surmounting the inteference caused by unavailable carbohydrate on water and cation absorption from the cecum and colon.

Further studies are needed to clarify the mechanism by which unavailable carbohydrate ingestion induces a rise in $(\mathrm{Na}+\mathrm{K})$ ATPase activity and an enlargement of cecum and colon.

\section{REFERENCES}

1) Burkitt, D. (1971): Epidemiology of cancer of the colon and rectum. Cancer, 28, 3-13.

2) Cummings, J. H. (1973): Dietary fiber. Gut, 14, 69-81.

3) Burkitt, D., Morley, D., and Walker, A. (1980): Dietary fiber in under- and overnutrition in childhood. Arch. Dis. Child., 55, 803-807.

4) Kelsay, J. L. (1978): A review of research on effects of fiber intake on man. Am. J. Clin. Nutr., 31, 142-159.

5) Trowell, H. C. (1960): Non-Infective Disease in Africa, Edward Arnold, London, p. 217.

6) Bingham, S., Williams, D. R. R., Cole, T. J., and James, W. P. T. (1979): Dietary fiber and regional large bowel cancer mortality in Britain. Br. J. Cancer, 40, 456-463.

7) Gear, J. S. S., Ware, A., Fursdon, P., Main, J. I., Nolan, D. J., Brodribb, A. J. M., and Vessey, M. P. (1979): Symptomless diverticular disease and intake of dietary fiber. Lancet, 10, 511-514.

8) Addis, T (1932): Hypertrophy of the gastrointestinal tract and high residue diets. Am.J. Physiol., 99, 417-423.

9) Oku, T., Yamada, K., and Hosoya, N. (1979): Effect of pullulan and cellulose on the gastrointestinal tract of rats. Eiyo To Shokuryo (J. Jap. Soc. Food Nutr.), 32, 235-241.

10) Oku, T., Konishi, F., and Hosoya, N. (1981): Effect of various unavailable carbohydrates and administrating periods on several physiological functions of rat. Eiyo To Shokuryo (J. Jap. Soc. Food Nutr.), 34, 437-443.

11) Inoue, Y., Moriuchi, S., and Hosoya, N. (1970): Effect of maltitol administration on the development of rats. Eiyo To Shokuryo (J. Jap. Soc. Food Nutr.), 23, 625-629.

12) Schneider, W. C. (1946): Phosphorus compounds in animal tissues: A comparison of methods for the estimation of nucleic acids. J. Biol. Chem., 164, 747-751.

13) Burton, K. (1956): A study of the conditions and mechanism of the diphenylamine reaction for the colorimetric estimation of DNA. Biochem. J., 62, 315-323.

14) Munro, H. N., and Fleck, A. (1966): Recent developments in the measurement of nucleic acids in biological materials. Analyst, 91, 78-88.

15) Lowry, O. H., Rosebrough, N. J., Farr, A. L., and Randall, R. J. (1951): Protein measurement with the Folin phenol reagent. J. Biol. Chem., 193, 265-275.

16) Schiffl, H., and Loeschke, K. (1977): Induction of $(\mathrm{Na}+\mathrm{K})$ ATPase in plasma membranes of rat cecum mucosa by diet: Time course and kinetics. Pflügers Arch., 372, 83-90.

17) Fiske, C. H., and Subbarow, Y. (1925): The colorimetric determination of phosphorus. 
J. Biol. Chem., 66, 375-400.

18) Loeschke, K., and Resch, W. (1977): Nucleic acid and protein content of rat cecum mucosa in dietary adaptation-growth by cellular hyperplasia. Pfiügers Arch.,372, 91-94.

19) Dowling, R. H., Riecken, E. O., Laws, J. W., and Booth, C. C. (1967): The intestinal response to high bulk feeding in the rat. Clin. Sci., 32, 1-9.

20) Loeschke, K., and Gordon, H. A. (1970): Water movement across the cecal wall of the germ free rat. Proc. Soc. Exp. Biol. Med., 133, 1217-1222.

21) Murray, D., Fleizer, D., and McArdle, A. H. (1980): Effect of dietary fiber on intestinal mucosal sodium-potassium-activated ATPase. J. Surg. Res., 29, 135-140. 